Short Review

\title{
The Piezoelectric Biosensors: Principles and Applications, a Review
}

\section{Miroslav Pohanka}

Faculty of Military Health Sciences, University of Defense, Trebesska 1575, Hradec Kralove, Czech Republic; Department of Geology and Pedology, Mendel University in Brno, Czech Republic E-mail: miroslav.pohanka@gmail.com

doi: $10.20964 / 2017.01 .44$

Received: 7 August 2016 / Accepted: 27 August 2016 / Published: 12 December 2016

Piezoelectric materials have broad use in many technological applications and they are frequently embedded in electronic devices. In principle, the piezoelectric materials work as oscillators on piezoelectric effect principle and interaction with their surface is easily detectable hence they are well suitable for construction of biosensors recognizing affinity interactions. Assays based on reaction between antigen and antibody, two polynucleotide strains, aptamer and protein are well suited for such studies. The current review is focused on explaining of the piezoelectric biosensors function, data about available materials and examples of analytical applications. Survey of actual literature is provided here.

Keywords: acoustic sensor; piezoelectric; quartz crystal microbalance; QCM; anisotropy; biosensor; oscillation; label free; immunosensor

\section{FULL TEXT}

(C) 2017 The Authors. Published by ESG (www.electrochemsci.org). This article is an open access article distributed under the terms and conditions of the Creative Commons Attribution license (http://creativecommons.org/licenses/by/4.0/). 